\title{
Genetic counselling in facioscapulohumeral muscular dystrophy
}

\author{
P W Lunt, P S Harper
}

\begin{abstract}
Clinical data are presented from a survey of 41 families with dominantly inherited facioscapulohumeral muscular dystrophy (FSHD) in which over 500 family members were examined, including 168 affected subjects. New mutation could account for six isolated cases. Results suggest that $33 \%$ of heterozygotes over 40 years are mildly affected and a majority develop significant lower limb weakness; $19 \%$ over 40 years require wheelchairs. Presymptomatic testing of serum creatine kinase level (CK) is limited as a raised level occurs in only $80 \%$ of affected males under 40 years and $48 \%$ of affected women. Distribution of weakness, severity, age at onset, and CK varied between subjects, but provided no clinical evidence for genetic heterogeneity in a comparison between the 11 largest families. The conclusion of genetic homogeneity in FSHD, including subjects previously diagnosed as FSH type spinal muscular atrophy, is strongly supported by recent genetic linkage data.
\end{abstract}

Facioscapulohumeral muscular dystrophy (FSHD) is a dominantly inherited condition with a variable age of onset and wide range of clinical expression. ${ }^{1}$ Although there are descriptions by Duchenne ${ }^{2}$ of patients conforming to a diagnosis of FSHD, first recognition and full description of FSHD as a genetic entity was by Landouzy and Déjérine, ${ }^{3}$ who reported two families with onset in childhood of facial weakness progressing to shoulder girdle weakness in teenage and lower limb weakness later in life.

Clinical Genetics Unit, Royal Hospital for Sick Children, St Michael's Hill, Bristol BS2 8BJ. P W Lunt

Institute of Medical Genetics, University of Wales College of Medicine, Heath Park, Cardiff CF4 4XN. P S Harper

Correspondence to Dr Lunt.

Received for publication 14 January 1991.

Revised version accepted for publication 9 April 1991.
The facial weakness characteristically involves the periorbital and perioral muscles, often asymmetrically, and is best demonstrated on attempting to puff out the cheeks or whistle. Periorbital weakness is recognised by weakness of eye closure, which if minimal, shows as inability to bury the eyelashes. ${ }^{4}$ Despite earlier onset facial weakness, symptomatic onset is usually in teenage with shoulder girdle weakness, which is often initially unilateral, predominantly right sided, and may correlate with handedness. ${ }^{5-7}$ Periscapular wasting and weakness resulting in scapular winging and inability to abduct the arm above the horizontal may be evident. Wasting and weakness of upper arm muscles often develops; distal progression leads to eventual weakness of wrist and finger extensors. ${ }^{1}$

While for some subjects muscle weakness remains restricted to a facioscapulohumeral distribution, in many others truncal, pelvic girdle, and lower limb muscles are also involved. The anterior tibial and peroneal muscles are often affected before more proximal ones, leading to the typical 'steppage' gait of this 'facioscapuloperoneal' presentation. Alternatively, lower limb weakness may develop in a descending order involving proximal before distal muscles. These two alternative presentations have previously been interpreted by some authors ${ }^{8}$ as indicative of genetic heterogeneity; others have found both presentations in single kindreds. ${ }^{6}$ Truncal weakness may produce marked lumbar lordosis. Progression of weakness in those affected severely leads to proximal and distal weakness in both upper and lower limbs with requirement for a wheelchair. ${ }^{1}$ The extraocular and bulbar musculature are spared specifically. ${ }^{6}$

In seeking genetic counselling family members are concerned about the following: (1) risk of disability in their offspring, (2) own risk of disability, (3) appropriateness of exercise or other treatments, (4) prevalence of the disorder, (5) possibilities for predictive and prenatal testing.

\section{HOMOGENEITY OR HETEROGENEITY}

Reliable answers to these questions require study of possible genetic heterogeneity in FSHD, particularly regarding evidence for recessive inheritance and for separate genetic subgroups identifiable from 
clinical, electromyographic, histopathological, or, now, molecular genetic criteria. Recessive inheritance in facioscapulohumeral syndrome has been proposed for some families, especially with infantile onset. ${ }^{910}$ In many of these families minor signs of muscle weakness have been noted in one parent or in other members from previous generations. ${ }^{9-11}$ In other cases the presence of ptosis, which is not a feature of FSHD, suggests that an alternative diagnosis should be sought. ${ }^{12}$

Muscle histology in FSHD often shows a relatively normal appearance, or shows some increase in fibre size variation, occasional internalisation of nuclei, and inflammatory response indicative of a myopathy. Small angular fibres, which can be a feature of neurogenic conditions, are characteristic in FSHD. ${ }^{4}$ There are several reports of patients with FSH type spinal muscular atrophy ${ }^{13-15}$; clinical presentation seems to be indistinguishable from that of FSHD, raising doubt about whether the two conditions are separate genetic entities. ${ }^{6}$

\section{RISK OF DISABILITY IN OFFSPRING AND IN KNOWN HETEROZYGOTES}

In a study of 107 subjects of all ages with FSHD, Padberg ${ }^{6}$ found that six patients $(6 \%)$ were unable to walk, and an additional four patients (9\% in total) required the use of a wheelchair when outside their homes. Severity correlated with increasing age; nine of 10 subjects requiring wheelchairs were aged 50 years or over, constituting $21 \%$ of the patients in this age group. Padberg ${ }^{6}$ emphasised the high proportion $(30 \%)$ of affected subjects who are presymptomatic 'abortive' cases, unaware of their own affected status. Minor clinical signs can be excluded in a subject at risk of FSHD only following specific clinical examination.

In any assessment of disability risk, in order to avoid ascertainment bias and to allow for possible non-penetrance, data for severity distribution in affected cases remaining at $50 \%$ risk after ascertainment of at risk status should be combined with estimates for age dependent penetrance. ${ }^{16}$

\section{TREATMENTS/EXERCISE}

As in other types of muscular dystrophy, there are no specific cures or treatments available, and the optimum level of exercise is unknown. Surgical treatment by scapular fixation ${ }^{17}$ has been very successful in some cases (G Padberg, personal communication).

\section{PREVALENCE}

Previous estimates of prevalence have varied widely from 1 per 435000 in Wisconsin, USA, ${ }^{18}$ to between
1 per $17000^{5}$ and 1 per $250000^{19}$ in European populations. ${ }^{6}$ The highest estimates of prevalence for FSHD are those obtained by Becker ${ }^{5}$ and Padberg ${ }^{6}$ (who estimated prevalence in northern Holland as 1 per 21000 ). Both are based on careful family studies, suggesting that the lower estimates from other studies could reflect underascertainment of mildly affected cases.

\section{PREDICTIVE TESTING}

The moderate rise of serum creatine kinase (CK) seen in many FSHD patients, ${ }^{20}$ and the reported association of FSHD with retinal vascular abnormalities ${ }^{2122}$ or with hearing loss, ${ }^{2223}$ raise the possibility of preclinical detection of heterozygotes.

\section{THIS STUDY}

Presented here, in order to provide data for genetic counselling, are the clinical results from a study of 168 patients with FSHD from 41 families ascertained primarily for a gene mapping study. We have addressed the issues of heterogeneity, risk of disability, and asymmetry, and, in relation to presymptomatic testing, have studied serum CK, but not possible retinal or hearing abnormalities.

\section{MOLECULAR GENETIC STUDIES}

The recent assignment of the gene for FSHD to chromosome $4^{24}$ undoubtedly will soon help to clarify some of these counselling issues. Initial results find no evidence for locus heterogeneity in FSHD, ${ }^{25}$ suggest that at least in some families diagnosed as FSH type spinal muscular atrophy the same genetic locus is involved, ${ }^{25}$ and question the specificity of previously reported retinal vascular changes. ${ }^{2126}$

\section{Material and methods}

Each family was ascertained through an index case in whom a diagnosis of FSH muscular dystrophy was supported by myopathic EMG or dystrophic changes on muscle biopsy. The study included families of all 24 cases of FSHD known previously to the Departments of Genetics or Neurology at the University Hospital of Wales, eight families referred to us for participation in a genetic linkage study, and nine families willing to participate after contact through the Muscular Dystrophy Group of Great Britain. Facial weakness was required to be present in at least one member from each kindred and three small families were excluded on this account. Three families are included (families 025, 034, and 067) in which diagnoses of FSH muscular dystrophy and FSH type spinal muscular atrophy had been made in different members investigated in different centres. 
Home visits were made to as many family members as possible; all affected and at risk subjects were examined, usually in their own homes. Blood was taken for DNA extraction for use in genetic linkage studies, and for creatine kinase (CK) assay from affected and at risk subjects as appropriate.

Individual muscle strength was graded for each affected subject according to the MRC scale ${ }^{27}$; the distribution of muscles with strength MRC grade 4- or less (or of any muscle weakness in less affected subjects) was charted. Subjects were classified as 'mildly', 'moderately', or 'severely' affected from the MRC grading of limb girdle and other proximal musculature as follows. Mild. No proximal muscle (limb girdles, upper arm, thigh, and calf muscles) weaker than MRC grade 4 (facial, truncal, and peroneal/anterior tibial muscles excluded). Moderate. One or more proximal muscles at MRC grade 4- or weaker; ambulation maintained. Severe. Pelvic girdle or proximal lower limb muscle at or below MRC grade 2; wheelchair required.

Empirical combinations of 'hard' and 'soft' signs based on MRC graded muscle strengths and serum CK level were used to score clinical status in subjects with minimal or equivocal clinical signs. ${ }^{16}$ Reported age at onset was recorded from subjects' recall of symptoms, or, in presymptomatic 'abortive' cases, from age at first recognition of clinical signs.

\section{Results}

\section{INHERITANCE}

Over 500 subjects from 41 families with FSHD were studied; 168 subjects were affected, 22 subjects over the age of 15 were scored as equivocal and excluded from further analysis, and approximately 330 appeared to be unaffected. Dominant inheritance could be proven in 28 families; in 17 of these at least four affected subjects were examined. There was no good evidence for recessive inheritance in the remaining families. In particular, there was no parental consanguinity in six isolated cases for whom both parents were unaffected on examination, nor in a further three cases where parental examination was not possible. Although the six isolated cases on average were younger and less severely affected than 28 other probands with FSHD from families with proven dominant inheritance (table 1), the difference, which could be expected with ascertainment of cases of new mutation for a dominant gene, was not significant, and provides no evidence to suggest that isolated cases have a different condition. Paternal age at the birth of the six proven isolated cases ranged from 22 to 42 years (mean 31.0 years); maternal age was 17 to 35 years (mean $25 \cdot 8$ ) years). An example of probable new mutation for dominantly inherited FSHD occurred in one family (FSH 062) where both parents of an affected woman were unaffected, although she had several affected children. The woman's parents were aged 21 and 20 years at her birth. There were two families with affected, but apparently isolated, sibs; the parents of one sibship (FSH 058) both showed equivocal signs and neither could be scored as affected; the father of the other sibship (FSH 080) was dead.

\section{PREVALENCE}

Prevalence was estimated from cases resident in Wales on 1.7.86, using population figures for $1984 .^{28}$ There were 56 cases ascertained from Wales (population 2.8 million), suggesting a minimum prevalence of 2.0/100 000. Within Cardiff (population 0.28 million) there were 12 cases (local prevalence 4.3/ 100000 ) and from the rest of Glamorgan (population 1.01 million) there were 22 cases (prevalence $2 \cdot 2 / 100000$ ). A further 15 young children resident in Wales were at close to $50 \%$ risk, suggesting a minimum birth incidence of $1 / 44000$.

\section{RISK OF DISABILITY}

Genetic counselling in FSHD requires reliable data for age dependent penetrance. Estimates of penetrance were obtained from this study, as discussed in

Table 1 Comparison of isolated cases (both parents examined) with other probands (from families with proven dominant inheritance).

\begin{tabular}{|c|c|c|c|c|c|c|}
\hline & $\begin{array}{l}\text { Sex ratio } \\
\mathbf{M}: \mathbf{F}\end{array}$ & $\begin{array}{c}\text { Average } \\
\text { age }\end{array}$ & $\begin{array}{c}\text { Average } \\
\text { onset age }\end{array}$ & Severity & $\begin{array}{c}\text { Average CK } \\
\text { (IU/1) } \\
(M 0-195) \\
(\text { F } 0-175)\end{array}$ & $\begin{array}{l}\text { Weakness } \\
\text { distribution* }\end{array}$ \\
\hline 6 isolated cases & $3: 3$ & $24 y$ & $12 y$ & $\begin{array}{l}\text { Mild }- \\
\text { Mod } 67 \% \\
\text { Sev } 33 \%\end{array}$ & $\begin{array}{l}\text { M } 352 \\
\text { F } 149\end{array}$ & $\begin{aligned} \text { FS } & 1 \\
\text { FSP } & 1 \\
\text { FSL } & 1\end{aligned}$ \\
\hline 28 probands & $12: 16$ & $37 y$ & $14 \mathrm{y}$ & $\begin{array}{l}\text { Mild } 7 \% \\
\text { Mod } 36 \% \\
\text { Sev } 57 \%\end{array}$ & $\begin{array}{l}\text { M } 405 \\
\text { F } 275\end{array}$ & $\begin{array}{rr}\text { FS } & 4 \\
\text { FSP } & 1 \\
\text { FSL } & 5 \\
\text { FSLP } & 18\end{array}$ \\
\hline
\end{tabular}

Difference between average age: $t=0.63$, df $32, \mathrm{p}=\mathrm{NS}$.

* $F=$ facial. $S=$ scapulohumeral. $L=$ proximal lower limb. $P=$ peroneal/anterior tibial. 
detail previously, ${ }^{16}$ by cross sectional analysis of segregation ratio in members of sibships selected for $50 \%$ risk of heterozygote status after ascertainment of at risk status. The results suggested penetrance values of $<5 \%$ at 0 to 4 years, $21 \%$ at 5 to 9 years, $58 \%$ at 10 to 14 years, $86 \%$ at 15 to 19 years, and $95 \%$ at 20 years and over. There was no detectable difference in reported age at onset according to the sex or age at onset of the affected parent. ${ }^{16}$

The distribution of severity by age and sex is shown in table 2 for the same subgroup of 54 affected subjects, selected for minimisation of ascertainment bias. The apparent greater severity in men (39\% mild, $35 \%$ moderate, $26 \%$ severe) compared to women $(58 \%$ mild, $36 \%$ moderate, $6 \%$ severe) was not significant $\left(\chi_{2}^{2}=4.4, p>0.1\right)$, but severity did increase significantly with age $\left(\chi_{4}^{2}=10 \cdot 4\right.$, $p<0.05$ ). With sexes combined, $48 \%$ of affected subjects aged 20 to 40 years were mild, $36 \%$ moderate, and $16 \%$ severe. For those over 40 years, $33 \%$ were mild, $48 \%$ moderate, and $19 \%$ severe. Severe cases can occur in childhood; a boy aged 12 years and two girls aged 15 years who required wheelchairs were encountered in the study. Among 133 affected subjects (including probands) from the 17 families in which at least four affected subjects were examined, significant proximal lower limb weakness was present in $7 / 18(39 \%)$ aged $<20$ years, in $27 / 59$ (46\%) aged 20 to 40 years, and in $38 / 56(68 \%)$ aged over 40 years. Table 3 shows the average reported age of onset in 69 affected subjects now aged over 40 years, according to their current severity grading. Overall, the greater the eventual severity, the younger was the reported age at onset, suggesting that early onset is associated with the greatest chance of disability in later life. Since $25 / 26$ subjects from the severe group were aware of symptoms by 21 years of age, at risk subjects remaining asymptomatic by that age can be reassured against developing severe disability.

Comparison of severity between offspring and parent in the 17 largest families (table 4) suggests that this may show a familial tendency $(39 \%$ of affected offspring of mildly affected parents were mild, $43 \%$ were moderate, and $18 \%$ were severe, compared to $28 \%$ offspring mildly affected, $44 \%$ moderately, and $28 \%$ severely from severely affected parents), but the differences did not reach significance $\left(\chi_{4}^{2}=4.84, p>0.3\right)$. Similarly, although the offspring of affected women appeared on average to be more severely affected $(23 \%$ mild, $49 \%$ moderate, $28 \%$ severe) than the offspring of affected men ( $30 \%$ mild, $51 \%$ moderate, $19 \%$ severe), the difference was not significant $\left(\chi_{2}^{2}=1.37, p>0.5\right)$.

\section{ASYMMETRY}

Asymmetry of scapular and upper limb involvement was evident in $65 \%$ of 113 affected subjects. The right side was preferentially involved in $56 / 74(76 \%)$

Table 2 Severity by age and by sex (for family members for whom ascertainment bias is minimised). ${ }^{16}$

\begin{tabular}{|c|c|c|c|c|}
\hline \multirow[b]{2}{*}{ Age/sex } & \multirow{2}{*}{$\begin{array}{c}\text { Total } \\
(100 \%)\end{array}$} & \multicolumn{3}{|c|}{ Severity (\% in each grade) } \\
\hline & & Mild & Moderate & Severe \\
\hline $\begin{array}{l}\text { Male } \\
<20 \text { years } \\
20-40 \text { years } \\
>40 \text { years }\end{array}$ & $\begin{array}{r}3 \\
14 \\
6\end{array}$ & $\begin{array}{r}100 \\
36 \\
17\end{array}$ & $\begin{array}{l}\overline{36} \\
50\end{array}$ & $\begin{array}{l}\overline{28} \\
33\end{array}$ \\
\hline $\begin{array}{r}\text { Female } \\
<20 \text { years } \\
20-40 \text { years } \\
>40 \text { years }\end{array}$ & $\begin{array}{r}5 \\
11 \\
15\end{array}$ & $\begin{array}{r}100 \\
64 \\
40\end{array}$ & $\begin{array}{l}-\overline{36} \\
47\end{array}$ & $\frac{\overline{1}}{13}$ \\
\hline $\begin{array}{c}\text { Sexes combined } \\
<20 \text { years } \\
20-40 \text { years } \\
>40 \text { years } \\
\text { Male - all ages } \\
\text { Female - all ages }\end{array}$ & $\begin{array}{r}8 \\
25 \\
21 \\
23 \\
31\end{array}$ & $\begin{array}{c}100 \\
48 \\
33 \\
9(39 \%) \\
18(58 \%)\end{array}$ & $\begin{array}{c}\overline{36} \\
48 \\
8(35 \%) \\
11(36 \%)\end{array}$ & $\begin{array}{c}\overline{16} \\
19 \\
6(26 \%) \\
2(6 \%)\end{array}$ \\
\hline
\end{tabular}

Severity on sex: $\chi_{2}^{2}=4 \cdot 4, p>0 \cdot 1$. Severity on age: $\chi_{4}^{2}=10 \cdot 4, p<0.05$.

Table 3 Reported age of onset by severity in affected subjects now aged $>40$ years.

\begin{tabular}{lcccc}
\hline Severity & $\begin{array}{c}\text { No of } \\
\text { subjects }\end{array}$ & $\begin{array}{c}\text { Mean present } \\
\text { age }(y)\end{array}$ & $\begin{array}{c}\text { Mean reported } \\
\text { age of onset }(y)\end{array}$ & $\begin{array}{c}\text { Range of reported } \\
\text { age of onset }(y)\end{array}$ \\
\hline Mild & 13 & 57 & 52 & $37-70$ \\
Moderate & 30 & 55 & 28 & $10-71$ \\
Severe & 26 & 52 & 14 & $5-21$ \\
& & & (one case 35) \\
\hline
\end{tabular}


Table 4 Severity distribution of offspring (over 20 years) by sex and severity of affected parent (all families with at least four affected).

\begin{tabular}{lcccc}
\hline & $\begin{array}{c}\text { Total } \\
\text { offspring } \\
\text { of affected parent }\end{array}$ & \multicolumn{3}{c}{ Severity in affected offspring $>20$ years } \\
\cline { 3 - 5 } & $(100 \%)$ & Mild (\%) & Moderate (\%) & Severe (\%) \\
\hline Male (all grades) & 43 & 30 & 51 & 19 \\
Female (all grades) & 61 & 23 & 49 & 28 \\
Total & 104 & 26 & 43 & 18 \\
Sex combined & 28 & 39 & 57 & 25 \\
$\quad$ Mild & 51 & 18 & 44 & 28 \\
Moderate & 25 & 28 & 43 & \\
\hline
\end{tabular}

Severity of offspring on severity of parent: $\chi_{4}^{2}=4 \cdot 84, p>0.3$.

Severity of offspring on sex of parent: $\chi_{2}^{2}=1.37, p>0.5$.

of those with asymmetry $\left(\chi_{1}^{2}=18.5, p=<0.001\right)$, but a possible correlation with handedness (right side weaker in $58 \%$ of 72 right handers, $25 \%$ of eight left handers; left side weaker in $15 \%$ of right handers, $37 \%$ of left handers) did not reach significance $\left(\chi_{1}^{2}=2 \cdot 00, p=>0 \cdot 1\right)$.

\section{CK AS PREDICTIVE TEST}

In order to test the appropriateness of serum creatine kinase as a diagnostic indicator, or as a presymptomatic marker, values are shown in table 5 by age, sex, and severity. Comparison by sex and severity with values obtained from apparently unaffected subjects at $25 \%$ or $50 \%$ pedigree determined risk is shown in the figure. CK was raised in a higher proportion of affected males $(73 \%)$ than affected

Table 5 Serum creatine kinase: proportion with raised level by age, sex, and severity (all affected).

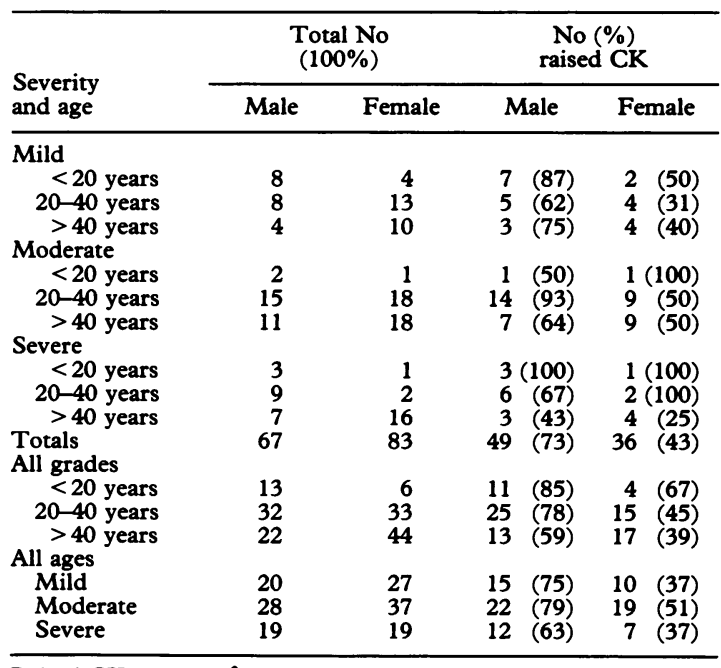

Raised CK on sex: $\chi_{1}^{2}=11.5, p=<0.001$.

Raised CK on severity: $\chi_{2}^{2}=2 \cdot 05, \mathrm{p}=\mathrm{NS}$.

Raised CK on age: $\chi_{2}^{2}=7 \cdot 8, p=<0.05$. females $(43 \%)\left(\chi_{1}^{2}=11.5, p=<0.001\right)$. This difference might relate to exercise level, particularly if males with FSHD exercise more than females (perhaps in an attempt to build up wasted muscles), or if exercise releases more $\mathrm{CK}$ from dystrophic muscle in males than in females. Although the highest values of CK occurred in severely affected males, there was no overall correlation with severity (table 5). High values were seen in some at risk young adult males (figure), raising the possibility that some of these may be presymptomatic. The observed inverse correlation of raised CK in FSHD with age (table 5) may lend support to this; however, since for mildly affected subjects aged 0 to 20 years, $7 / 8$ males $(88 \%)$ but only $2 / 4$ females ( $50 \%$ ) had raised CK, and for mildly affected subjects aged over 20 years CK was raised in only $8 / 12$ men $(67 \%)$ and $8 / 23$ women $(35 \%)$, the use of $\mathrm{CK}$ as a presymptomatic test would seem to be limited.

\section{CLINICAL EVIDENCE FOR HETEROGENEITY}

In order to identify any clinical evidence for genetic heterogeneity, clinical parameters were studied in the 11 largest families, in each of which at least six affected subjects had been examined. The distribution of most significant muscle weakness for each affected subject is shown in table 6. One apparently unaffected probable obligate carrier was identified (family FSH 028; the subject and her children who scored as affected by the empirical criteria are not shown on the pedigree in the accompanying paper. ${ }^{26}$ In only one other subject (from a total of 113) was there no detectable facial weakness (family FSH 025). In the three largest pedigrees (FSH 001, 009, 067) and in one smaller pedigree (FSH 087) both a facioscapuloperoneal presentation and initial proximal involvement of the lower limbs had occurred in different subjects. Comparison was made (table 7) between the average reported age at onset, average serum CK, proportion with lower limb involvement, proportion affected mildly or severely, and proportion with early peroneal involvement (facioscapuloperoneal presentation). For each of these parameters 
Males

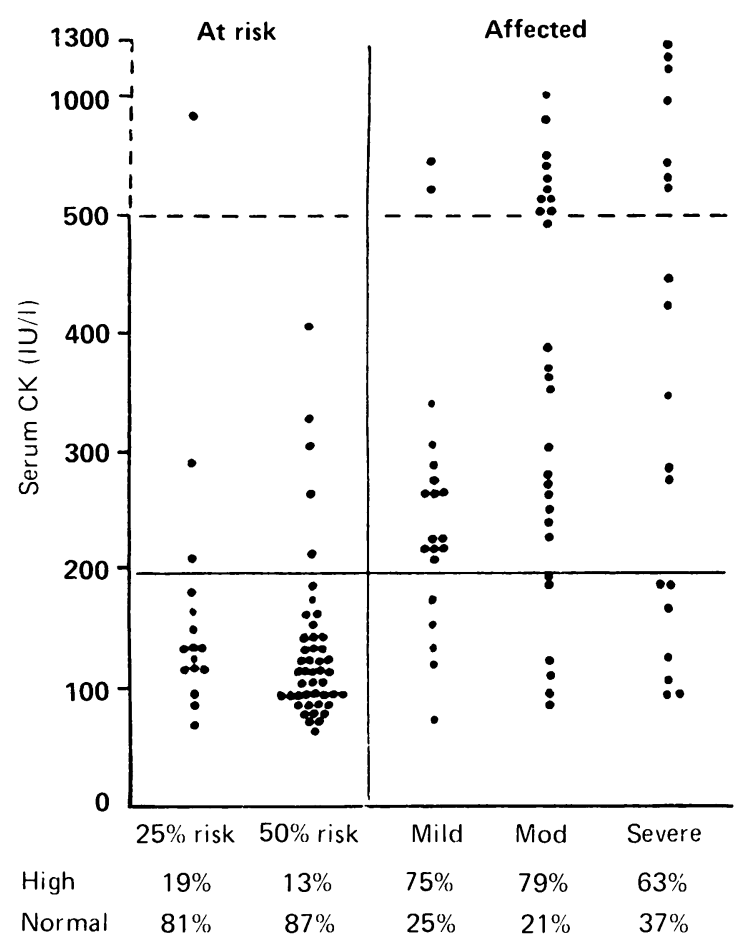

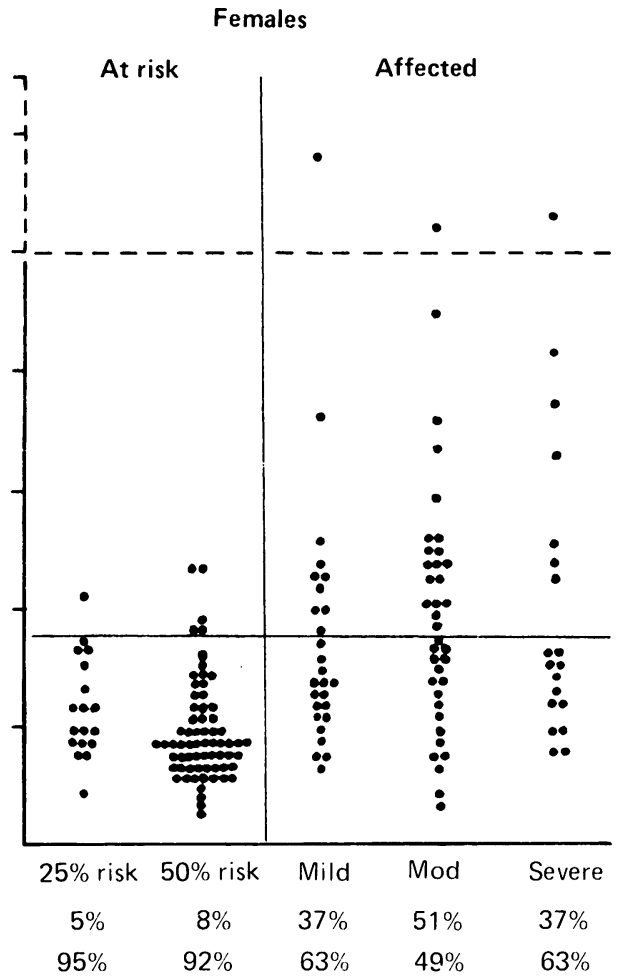

Distribution of $C K$ values in FSHD.

the 11 families were placed in rank order (table 8), choosing the polarity of rank to highlight any recognisable differences between the families.

No clear clinical distinction could be made between the 11 families. The rank order analysis showed that families FSH 006 and 087 could be used to define the two ends of a continuous clinical spectrum, but one which could not be accounted for by difference in average age at examination ( 33 years for FSH 006, 30 years for FSH 087). Family 087 is typified by early age at onset, proximal lower limb involvement, and normal CK. Subjects in family 006 tend to be mildly affected, have a late reported age of onset, and high CK. Neither of these families was one in which a diagnosis of FSH-SMA had been applied to any subjects.

Table 6 Distribution of weakness in the 11 largest families.

\begin{tabular}{|c|c|c|c|c|c|c|c|c|c|c|c|}
\hline \multirow[b]{2}{*}{ Family } & \multirow[b]{2}{*}{ Affected } & \multirow{2}{*}{$\begin{array}{c}\text { Average } \\
\text { age }(y)\end{array}$} & \multicolumn{9}{|c|}{ Muscle groups involved* } \\
\hline & & & Nil & SP & $\mathbf{F}$ & FS & FSL & FL & FSP & FP & FSLP \\
\hline $\begin{array}{l}012 \\
025 \\
067 \\
009 \\
035 \\
005 \\
026 \\
001 \\
006 \\
028 \\
087\end{array}$ & $\begin{array}{r}6 \\
10 \\
16 \\
15 \\
12 \\
7 \\
7 \\
17 \\
11 \\
6 \\
7\end{array}$ & $\begin{array}{l}46 \\
43 \\
41 \\
39 \\
38 \\
38 \\
36 \\
34 \\
33 \\
33 \\
30\end{array}$ & $\begin{array}{l}- \\
\overline{-} \\
- \\
\overline{-} \\
\overline{-} \\
\overline{-} \\
\overline{1} \\
-\end{array}$ & $\begin{array}{l}\overline{1} \\
- \\
- \\
- \\
- \\
- \\
- \\
- \\
- \\
-\end{array}$ & $\begin{array}{l}\overline{1} \\
1 \\
- \\
- \\
\overline{-} \\
\overline{1} \\
1 \\
\overline{-}\end{array}$ & $\begin{array}{l}2 \\
4 \\
3 \\
4 \\
4 \\
2 \\
6 \\
4 \\
6 \\
3 \\
-\end{array}$ & $\begin{array}{l}1 \\
4 \\
1 \\
- \\
- \\
- \\
4 \\
2 \\
1 \\
2\end{array}$ & $\begin{array}{l}- \\
\overline{-} \\
- \\
- \\
\overline{-} \\
\overline{1} \\
- \\
- \\
-\end{array}$ & $\begin{array}{l}\overline{1} \\
3 \\
1 \\
1 \\
- \\
\overline{2} \\
- \\
\overline{1} \\
-\end{array}$ & $\begin{array}{l}- \\
- \\
- \\
- \\
- \\
- \\
- \\
- \\
-\end{array}$ & $\begin{array}{l}3 \\
3 \\
4 \\
9 \\
7 \\
5 \\
1 \\
5 \\
2 \\
1 \\
4\end{array}$ \\
\hline
\end{tabular}

${ }^{*} \mathrm{~F}=$ facial. $\mathrm{S}=$ scapulohumeral. $\mathrm{L}=$ proximal lower limb. $\mathrm{P}=$ peroneal/anterior tibial. 
Table 7 Clinical parameters for affected subjects in the 11 largest families.

\begin{tabular}{|c|c|c|c|c|c|c|c|c|c|c|c|}
\hline & \multicolumn{11}{|c|}{ Family (ordered by age at examination) } \\
\hline & 012 & 025 & 067 & 009 & 035 & 005 & 026 & 001 & 006 & 028 & 087 \\
\hline $\begin{array}{l}\text { Family data } \\
\text { Affected subjects examined } \\
\text { Male: female } \\
\text { Average age at examination } \\
\quad(y)\end{array}$ & $\begin{array}{c}6 \\
3: 3 \\
46\end{array}$ & $\begin{array}{c}10 \\
3: 7 \\
43\end{array}$ & $\begin{array}{c}15 \\
7: 8 \\
41\end{array}$ & $\begin{array}{c}15 \\
8: 7 \\
39\end{array}$ & $\begin{array}{c}12 \\
5: 7 \\
38\end{array}$ & $\begin{array}{c}7 \\
3: 4 \\
38\end{array}$ & $\begin{array}{c}7 \\
3: 4 \\
36\end{array}$ & $\begin{array}{c}17 \\
7: 10 \\
34\end{array}$ & $\begin{array}{c}11 \\
5: 6 \\
33\end{array}$ & $\begin{array}{c}6 \\
2: 4 \\
33\end{array}$ & $\begin{array}{c}7 \\
5: 2 \\
30\end{array}$ \\
\hline $\begin{array}{l}\text { Onset age } \\
\text { Median reported onset age } \\
\text { (y) }\end{array}$ & 20 & 22 & 17 & 15 & 21 & 16 & 20 & 19 & 22 & 15 & 13 \\
\hline $\begin{array}{l}\text { Severity } \\
\% \text { mild } \\
\% \text { moderate } \\
\% \text { severe }\end{array}$ & $\begin{array}{l}15 \\
70 \\
15\end{array}$ & $\begin{array}{l}50 \\
40 \\
10\end{array}$ & $\begin{array}{l}40 \\
35 \\
25\end{array}$ & $\begin{array}{l}25 \\
40 \\
35\end{array}$ & $\begin{array}{l}15 \\
70 \\
15\end{array}$ & $\begin{array}{l}30 \\
40 \\
30\end{array}$ & $\begin{array}{l}30 \\
70 \\
-\end{array}$ & $\begin{array}{l}30 \\
45 \\
25\end{array}$ & $\begin{array}{l}80 \\
10 \\
10\end{array}$ & $\begin{array}{l}70 \\
15 \\
15\end{array}$ & $\begin{array}{l}15 \\
70 \\
15\end{array}$ \\
\hline $\begin{array}{l}\text { Distribution } \\
\% \text { with pelvic or proximal } \\
\text { lower limb weakness }\end{array}$ & 65 & 30 & 55 & 65 & 60 & 70 & 15 & 60 & 35 & 35 & 85 \\
\hline $\begin{array}{l}\% \text { definitely FSP } \\
\text { presentation } \\
\% \text { definitely proximal lower } \\
\text { limb weak before peroneal }\end{array}$ & $\begin{array}{l}- \\
17\end{array}$ & $\begin{array}{l}20 \\
-\end{array}$ & $\begin{array}{l}20 \\
27\end{array}$ & $\begin{array}{l}7 \\
7\end{array}$ & - & - & - & $\begin{array}{l}12 \\
29\end{array}$ & $\begin{array}{l}- \\
18\end{array}$ & $\begin{array}{l}- \\
17\end{array}$ & $\begin{array}{l}14 \\
-\end{array}$ \\
\hline $\begin{array}{l}C K \\
\% \text { normal CK } \\
\% \text { moderately raised CK } \\
(1-2 \times \text { normal limit })\end{array}$ & $\overline{65}$ & $\begin{array}{l}60 \\
30\end{array}$ & $\begin{array}{l}35 \\
40\end{array}$ & $\begin{array}{l}50 \\
35\end{array}$ & $\begin{array}{l}50 \\
15\end{array}$ & $\begin{array}{l}30 \\
55\end{array}$ & $\begin{array}{l}70 \\
30\end{array}$ & $\begin{array}{l}10 \\
75\end{array}$ & $\begin{array}{l}20 \\
40\end{array}$ & $\begin{array}{l}35 \\
65\end{array}$ & $\begin{array}{l}55 \\
30\end{array}$ \\
\hline $\begin{array}{l}\% \text { high CK ( }>2 \times \text { normal } \\
\text { limit) }\end{array}$ & 35 & 10 & 25 & 15 & 35 & 15 & - & 15 & 40 & - & 15 \\
\hline
\end{tabular}

Table 8 Rank order of 11 largest families for various parameters.

\begin{tabular}{|c|c|c|c|c|c|c|c|c|c|c|c|}
\hline & \multicolumn{11}{|c|}{ Family (ordered by age at examination) } \\
\hline & 012 & 025 & 067 & 009 & 035 & 005 & 026 & 001 & 006 & 028 & 087 \\
\hline $\begin{array}{l}\text { Average current age } \\
(1=\text { youngest })\end{array}$ & 11 & 10 & 9 & 8 & 7 & 6 & 5 & 4 & 3 & 2 & 1 \\
\hline $\begin{array}{c}\text { Median age onset } \\
(1=\text { youngest })\end{array}$ & $7=$ & $10=$ & 5 & $2=$ & 9 & 4 & $7=$ & 6 & $10=$ & $2=$ & 1 \\
\hline $\begin{array}{l}\text { Severity } \\
\text { Proportion mild }(1=\text { lowest }) \\
\text { Proportion severe } \\
\quad(1=\text { highest })\end{array}$ & $\begin{array}{l}2= \\
5=\end{array}$ & $\begin{array}{l}9 \\
9\end{array}$ & $\begin{array}{l}8 \\
3\end{array}$ & $\begin{array}{l}4 \\
1\end{array}$ & $\begin{array}{l}2= \\
5=\end{array}$ & $\begin{array}{l}5= \\
2\end{array}$ & $\begin{array}{c}5= \\
11\end{array}$ & $\begin{array}{l}7 \\
4\end{array}$ & $\begin{array}{l}11 \\
10\end{array}$ & 10 & $\begin{array}{l}1 \\
8\end{array}$ \\
\hline $\begin{array}{l}\text { Distribution } \\
\text { Proportion with pelvic or } \\
\text { proximal lower limb } \\
\text { weakness }(1=\text { highest })\end{array}$ & $3=$ & 10 & 7 & $3=$ & 6 & 2 & 11 & 5 & 8 & 9 & 1 \\
\hline $\begin{array}{l}\text { Proportion FSP }(1=\text { highest }) \\
\text { Proportion proximal lower } \\
\text { limb weak before peroneal } \\
(1=\text { lowest })\end{array}$ & $\begin{array}{l}7= \\
7=\end{array}$ & $\begin{array}{l}1= \\
1=\end{array}$ & $1=$ & $\begin{array}{l}6 \\
6\end{array}$ & $\begin{array}{l}5 \\
1=\end{array}$ & $\begin{array}{l}7= \\
1=\end{array}$ & $\begin{array}{l}7= \\
1=\end{array}$ & $\begin{array}{r}4 \\
11\end{array}$ & $\begin{array}{l}7= \\
9\end{array}$ & $\begin{array}{l}7= \\
7=\end{array}$ & $3=$ \\
\hline $\begin{array}{l}C K \\
\text { Proportion normal CK } \\
\quad(1=\text { highest })\end{array}$ & 11 & 2 & $6=$ & 4 & 5 & 8 & 1 & 10 & 9 & $6=$ & 3 \\
\hline $\begin{array}{l}\text { Proportion high } \mathrm{CK}>2 \times \mathrm{N} \\
\quad(1=\text { lowest })\end{array}$ & $9=$ & 3 & 8 & 4 & $9=$ & $5=$ & $1=$ & 7 & 11 & $1=$ & $5=$ \\
\hline Average rank & $6 \cdot 4$ & $5 \cdot 6$ & $6 \cdot 0$ & 3.75 & $5 \cdot 25$ & $4 \cdot 25$ & $5 \cdot 5$ & $6 \cdot 75$ & $9 \cdot 4$ & 5.9 & $\underline{2 \cdot 9}$ \\
\hline
\end{tabular}

\section{Discussion}

DIAGNOSIS OF FSHD

Differentiation of facioscapulohumeral disease from other types of muscular dystrophy (limb girdle, scapulohumeral, and scapuloperoneal) in most cases is possible from recognition of early onset of characteristic facial weakness, shoulder girdle and upper limb involvement before pelvic girdle, and, where other family members can be examined, proven dominant inheritance. In this study, in only two of 
113 affected subjects from the 11 largest families was there no detectable facial weakness; one of these was an obligate carrier aged 42 years with complete nonpenetrance. In particular, the three small families referred to us as FSHD, but excluded from the study because none of the two to three affected subjects showed facial weakness, provide support for a dominantly inherited scapulohumeral or scapuloperoneal syndrome genetically distinct from FSHD.

\section{ISOLATED CASES}

Isolated cases of conditions normally showing dominant inheritance can be explained by new mutation, parental non-penetrance, or incorrectly assumed paternity. In FSHD, only if both parents have been found by examination to be clear can a case be accepted as 'isolated'. For the six cases in the present study there were no clear clinical differences from other probands. The lack of parental consanguinity argues against the possibility of recessive inheritance, although this has been noted in one other isolated case made known to us subsequent to this study (a boy aged 12 years, now moderately affected, who had onset with facial weakness in infancy).

\section{HOMOGENEITY OF FSHD}

Variation in presentation, distribution of weakness, and severity has fostered debate about possible genetic locus heterogeneity, particularly through comparison of individual subjects or small families.$^{29}$ In this study, comparison of clinical parameters in the 11 largest families (each with at least six affected subjects) indicates that the different modes of presentation, particularly with respect to pelvic and peroneal involvement, can be observed in the various members of large kindreds. Although we identified the two families which formed the opposite ends of a clinical spectrum defined by mean age at onset, average severity, and serum CK levels, the spectrum was continuous and the parameters provided no clinical evidence of significant genetic heterogeneity between the 11 largest families.

FSH type SMA with a dominant inheritance pattern was first proposed from reports of single cases and small families from Japan. ${ }^{1314}$ The diagnosis of FSH-SMA in branches of three of the families in the present study had been made elsewhere from interpretation of EMG and muscle biopsy findings. By analogy to reports of several males with limb girdle weakness, calf hypertrophy, and raised $\mathrm{CK}$, previously diagnosed from similar interpretation as SMA, but in whom the finding of dystrophin gene deletion established the diagnosis as Becker muscular dystrophy, ${ }^{3031}$ we did not feel that there was sufficient evidence to support the proposed existence of FSH type SMA as a separate genetic condition.

The consistency of close linkage of the disease locus to D4S139 in all informative families from our panel ${ }^{26}$ helps confirm the conclusion from this clinical study that FSHD is caused by mutations at a single genetic locus. In particular, this includes the three families (FSH 025, 034, 067) with branches diagnosed as FSH-SMA, and the two families (FSH 006, 087) forming the opposite ends of the clinical spectrum, even though in one of these (FSH 087) there has been a single recombination event between $D 4 S 139$ and $F S H D .{ }^{26}$ It remains to be seen whether families showing dominant inheritance for muscular dystrophy in limb girdle, scapulohumeral, or scapuloperoneal distribution and excluded from this study show similar genetic linkage.

The genetic homogeneity facilitates the answering of the questions raised by family members.

\section{PREVALENCE AND INCIDENCE}

The estimated birth incidence in Wales of 1/44000 is undoubtedly an underestimate. No attempt was made at complete ascertainment of families; the ascertainment of 4.4 cases $/ 100000$ from Cardiff is likely to be more appropriate, and is comparable with previous estimates for prevalence of $1 / 17000$ in South Baden, Germany ${ }^{5}$ or $1 / 21000$ in northern Holland. ${ }^{6}$

\section{DISABILITY}

In known affected subjects the risk of disability in later life can be assessed from the reported age at onset, together with the distribution and severity of weakness. Proximal lower limb weakness develops in the majority of subjects by middle age; occurrence by the age of 20 years increases the likelihood of eventual requirement for a wheelchair. The term 'facioscapulohumeral' may not be the most appropriate; indeed several subjects with lower limb weakness expressed considerable resentment that use of this term had suggested to them that the legs would remain unaffected. The term 'facioscapulolimb muscular dystrophy' should perhaps be considered as an alternative. For those born at $50 \%$ risk of inheriting FSHD, the likelihood of eventual disability is determined by the age dependent penetrance and the age related severity distribution. With penetrance reaching $95 \%$ by 20 years ${ }^{16}$ this study suggests that $19 \%$ of FSHD heterozygotes require a wheelchair by 40 years or over and $30 \%$ remain affected only mildly throughout life. Padberg $^{6}$ suggested that $9 \%$ require wheelchairs and $22 \%$ above 30 years remain as presymptomatic 'abortive' cases. 


\section{ASYMMETRY AND EXERCISE}

Results from this study support previous suggestions $^{5-7}$ that asymmetry of weakness, particularly at presentation in the upper limb and shoulder girdle, is usual and correlates with handedness. Because it is possible that the preferential use of one arm may hasten onset of dystrophy on that side, affected subjects should avoid overuse of limbs, and, in particular, the practising of body building exercises, favoured by many young men with FSHD concerned about their body image, should perhaps be discouraged.

\section{PRESYMPTOMATIC TESTS}

With penetrance estimated at $95 \%$ by the age of 20 years, presymptomatic tests in FSHD in addition to clinical examination are likely to play a rather limited role. This study suggests that the serum creatine kinase level in affected subjects reduces with increasing age, but shows little or no correlation with severity. Raised levels in only $12 / 16$ men and 6/17 women aged under 40 years and affected mildly suggests that the role of $\mathrm{CK}$ in presymptomatic testing should be to select those at risk subjects in whom further investigation is warranted. Further investigation might include EMG, muscle biopsy, muscle imaging techniques, audiography, and retinal fluorescein angiography, but the sensitivity and specificity of these as presymptomatic tests for FSHD is not known. Application of the close linkage of $D 4 S 139$ to $F S H D$ illustrates ${ }^{26}$ in some subjects from this study (families 005 and 006) that the DNA linkage results concord better with the scoring of affected or unaffected status from clinical criteria than from the interpretation ${ }^{21}$ of fluorescein angiograms.

\section{GENETIC LINKAGE}

The close linkage of D4S139 to FSHD now makes possible presymptomatic prediction and prenatal diagnosis in FSHD. By further analysis of these and other families it is hoped that the role of serum creatine kinase and retinal fluorescein angiography in presymptomatic testing, the reliability of the empirical method of scoring for affected status, and the possibility that other forms of muscular dystrophy could be caused by mutations at the FSHD locus can be assessed. The prospect of identifying the FSHD gene product from pursuit of physical methods for isolation and characterisation of the FSHD gene now provides a target for further research.

We wish to thank the members of the various families for their participation in this study. We thank Professor Alistair Compston for clinical advice and support, and the various clinicians who referred families to us, in particular Dr Robin Fitzsimons, Professor R H T Edwards, Dr J Morgan-Hughes, Dr D Gardner-Medwin, Dr Anita Harding, Dr J Graham, and Dr Sarah Bundey. PWL was funded for this study by the Muscular Dystrophy Group of Great Britain.

1 Walton J, Gardner-Medwin D. The muscular dystrophies. In: Walton J, ed. Disorders of voluntary muscle. 5th ed. Edinburgh: Churchill Livingstone, 1988.

2 Duchenne GB. Recherches sur la paralysie musculaire pseudohypertrophique ou paralysie myo-sclerosique. Arch Gen Med 1868;11:179-209.

3 Landouzy L, Déjérine J. De la myopathie atrophique progressive. Rev Med 1885;5:253-366.

4 Dubowitz V. Muscle disorders in childhood. Philadelphia: Saunders, 1978.

5 Becker PE. Dystrophia musculorum progressiva. Eine genetische und klinische untersuchung der muskeldystrophien. Stuttgart: Georg Thieme Verlag, 1953.

6 Padberg G. Facioscapulohumeral disease. MD thesis, University of Leiden, 1982.

7 Brouwer OF, Ruys CJM, van de Ploeg RJO, Padberg GW. Dynamometry in facioscapulohumeral muscular dystrophy. $\mathcal{F}$ Neurol Sci 1990;98(suppl):195.

8 Kazakov VM, Bogorodinsky DK, Znoyko ZV, Skorometz AA. The facio-scapulo-limb (or the facioscapulohumeral) type of muscular dystrophy. Eur Neurol 1974;11:236-60.

9 Small RG. Coats' disease and muscular dystrophy. Trans Am Acad Ophthalmol Otolaryngol 1968;72:225-31.

10 Korf BR, Bresnan MJ, Shapiro F, Sotrel A, Abroms IF. Facioscapulohumeral dystrophy presenting in infancy with facial diplegia and sensorineural deafness. Ann Neurol 1985;17:513-16.

11 McGarry J, Garg B, Silbert S. Death in childhood due to facioscapulo-humeral dystrophy. Acta Neurol Scand 1983;68:613.

12 Bailey RO, Marzulo DC, Hans MB. Infantile facioscapulohumeral muscular dystrophy: new observations. Acta Neurol Scand 1986;74:51-8.

13 Fenichel GM, Emery ES, Hunt P. Neurogenic atrophy simulating facioscapulohumeral dystrophy. Arch Neurol 1967; 17:257-60.

14 Furukawa T, Toyokura Y. Chronic spinal muscular atrophy type of facioscapulohumeral type. $\mathcal{F}$ Med Genet 1976;13:2859.

15 Siddique T, Roper H, Pericak-Vance MA, et al. Linkage analysis in the spinal muscular atrophy type of facioscapulohumeral disease. F Med Genet 1989;26:487-9.

16 Lunt PW, Compston DAS, Harper PS. Estimation of age dependent penetrance in facioscapulohumeral muscular dystrophy by minimising ascertainment bias. f Med Genet 1989;26:755-60.

17 Copeland SA, Howard RC. Thoracoscapular fusion for facioscapulohumeral dystrophy. F Bone foint Surg (Br) 1978; 60:547-51.

18 Morton NE, Chung CS. Formal genetics of muscular dystrophy. Am f Hum Genet 1959;11:360-79.

19 Prot J. Genetic-epidemiological studies in progressive muscular dystrophy. F Med Genet 1971;8:90-5.

20 Hughes BP. Creatine phosphokinase in facioscapulohumeral muscular dystrophy. $B M \mathcal{Y}$ 1971;3:464-5.

21 Fitzsimons RB, Gurwin EB, Bird AC. Retinal vascular abnormalities in facioscapulohumeral muscular dystrophy. Brain 1987;110:631-48.

22 Padberg GW, Brouwer OF, de Keizer RJW, Wijmenga C. Retinal vascular disease and perception deafness in facioscapulohumeral muscular dystrophy. f Neurol Sci 1990; 98(suppl):196-7.

23 Voit T, Lamprecht A, Lenard HG, Goebel HH. Hearing loss in facioscapulohumeral muscular dystrophy. Eur $\mathcal{F}$ Pediatr 1986;145:280-5.

24 Wijmenga C, Frants RR, Brouwer OF, Moerer P, Weber JL Padberg GW. The facioscapulohumeral muscular dystrophy gene maps to chromosome 4. Lancet 1990;ii:651-2. 
25 Upadhyaya M, Lunt PW, Sarfarazi M, et al. DNA marker for presymptomatic and prenatal diagnosis of facioscapulohumeral disease. Lancet 1990;ii:1320-1.

26 Upadhyaya M, Lunt PW, Sarfarazi M, et al. A closely linked DNA marker for facioscapulohumeral disease on chromosome 4q. F Med Genet 1991;28:665-71.

27 Medical Research Council. Aids to the examination of the peripheral nervous system. Memorandum No 45. London: HMSO, 1982.

28 Bartholomew J. Gazetteer of places in Britain. 2nd ed. Compiled Mason O. Edinburgh: John Bartholomew \& Son Ltd, 1986.
29 Kazakov VM, Bogorodinsky DK, Skorometz AA. The myogenic scapulo-peroneal syndrome. Muscular dystrophy in the $\mathrm{K}$ kindred: clinical study and genetics. Clin Genet 1976;10:41-50.

30 Lunt PW, Cumming WJK, Kingston $\mathrm{H}$, et al. DNA probes in differential diagnosis of Becker muscular dystrophy and spinal muscular atrophy. Lancet 1989;i:46-7.

31 Clarke A, Davies KE, Gardner-Medwin D, Burn J, Hudgson P. Xp21 DNA probe in diagnosis of muscular dystrophy and spinal muscular atrophy. Lancet 1989;i:443. 